$>$ SPECIAL ISSUE ON PALEOCEANOGRAPHY: LESSONS FOR A CHANGING WORLD

\title{
THE ANTARCTIC ICE SHEET
}

\section{A Paleoclimate Modeling Perspective}

\section{By Edward G.W. Gasson and Benjamin A. Keisling}

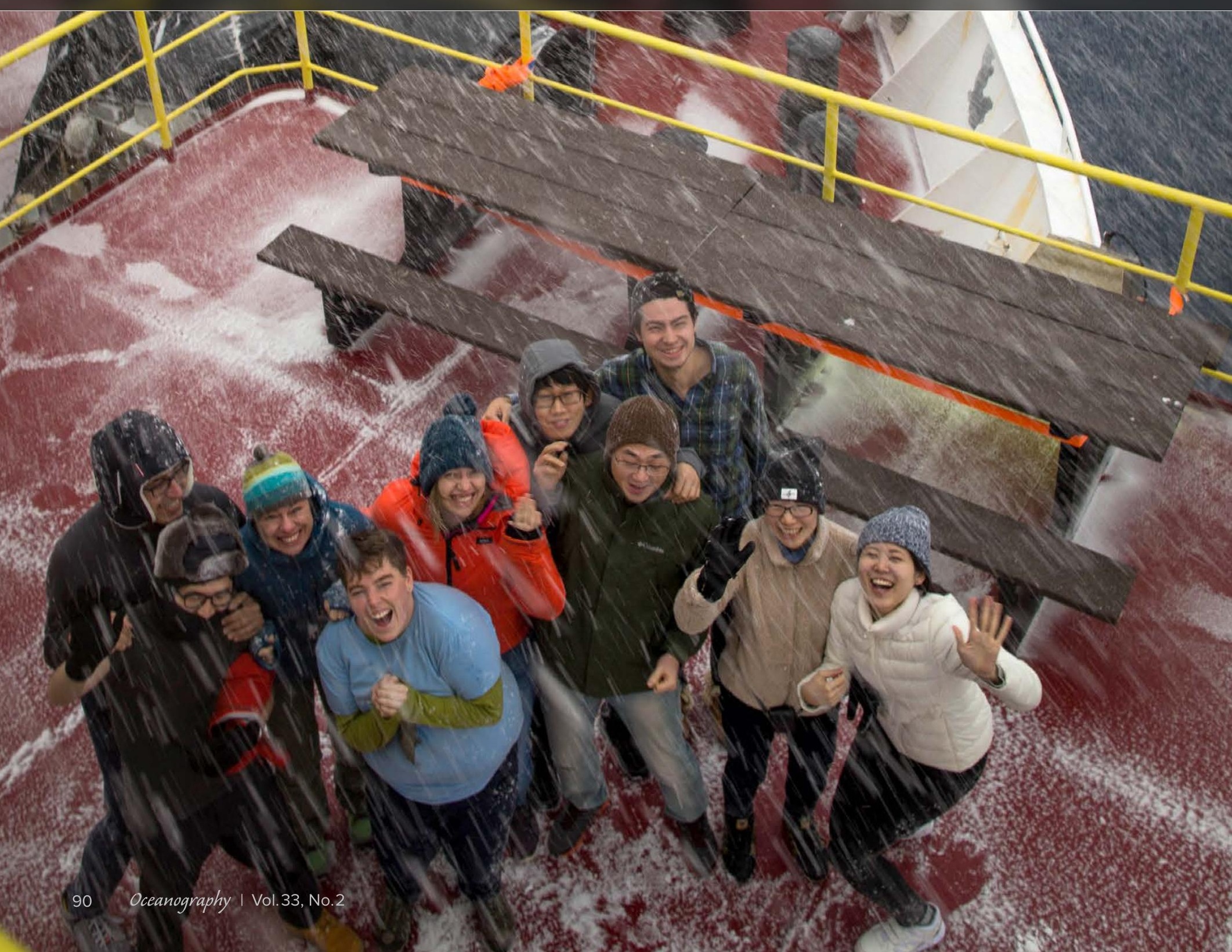


ABSTRACT. The Antarctic Ice Sheet is the largest potential contributor to future sea level rise. Models and paleoceanographic data are often used to examine the past behavior of the ice sheet during both cooler and warmer intervals to understand the forcing and feedbacks that influence ice sheet behavior. Marine geologic studies have focused on understanding ice sheet response during warmer intervals, including the middle Miocene and Pliocene, that have been considered potential analogues to future anthropogenic climate change. Here, we discuss ice sheet modeling and the ways that marine geologic data are used to constrain ice sheet models of the Antarctic Ice Sheet during past warm intervals. We focus on the key challenge of simulating retreat of the "marine" and "terrestrial" sectors of the ice sheet in the geologic past. By integrating ice sheet models and geologic records, we can better characterize the processes that drove past ice sheet retreat. A more complete understanding of these processes, based on continuing engagement between the data and the modeling communities, is the key to predicting the ice sheet's future.

\section{INTRODUCTION}

The Antarctic Ice Sheet is the largest component (by volume) of Earth's cryosphere. It has a major impact on both regional and global climate through the modification of surface albedo and by altering atmosphere and ocean circulation (DeConto et al., 2007; Bintanja et al., 2013; Colleoni et al., 2018; Golledge et al., 2019). The Antarctic Ice Sheet is the largest store of freshwater on Earth and has the potential to raise global sea level by $58 \mathrm{~m}$ if completely melted. Today, it receives $2,100 \mathrm{Gt}$ of annual snowfall that is balanced by mass lost from ice flowing under gravity toward the coast, where it is removed approximately equally by ocean melting of floating ice shelves and the calving of icebergs (Rignot et al., 2019). Unlike the Greenland Ice Sheet, which has an extensive ablation zone, there is minimal melting on the Antarctic Ice Sheet surface at present, although surface meltwater is found in small areas (Trusel et al., 2013; Kingslake et al., 2017; Lenaerts et al., 2017; Banwell et al., 2019).

Much of the ice sheet ( $23 \mathrm{~m}$ sea level equivalent) is "marine," meaning that it sits on bedrock currently below sea level (Fretwell et al., 2013) and is often buttressed by floating ice shelves. There are concerns about the role ocean warming plays regarding the future stability of these parts of the ice sheet (Alley et al.,
2015). Of particular concern is the stability of the smaller West Antarctic Ice Sheet if its supporting ice shelves should be lost (Mercer, 1978; Fürst et al., 2016; Pattyn, 2018). There is also growing appreciation that marine portions ( $\sim 19 \mathrm{~m}$ sea level equivalent) of the much larger East Antarctic Ice Sheet may be vulnerable to ocean warming (e.g., Rintoul et al., 2018; Wilson et al., 2018). Although today $\sim 40 \%$ of the Antarctic Ice Sheet volume sits on bedrock below sea level, the fraction that is marine has increased through time. This increase is a result of tectonics and glacial evolution, which carved Antarctica's landscapes, moved sediment to the expanding continental margins, and depressed the bedrock (Bart, 2003; Young et al., 2011; Colleoni et al., 2018; Paxman et al., 2018). Recent reconstructions of past Antarctic bedrock topography for a number of intervals show how the marine fraction of Antarctica has changed through time (Figure 1; Paxman et al., 2019).

The remainder of the Antarctic Ice Sheet is "terrestrial," that is, grounded on bedrock presently above sea level, so its stability is largely controlled by direct atmospheric melting and buttressing by surrounding ice and the basal topography (e.g., Morlighem et al., 2020). Most importantly, the marine sectors of the ice sheet have the potential to lose mass through ocean-driven melting and iceberg calving, as well as surface melting, whereas the terrestrial sectors lose mass when surface melting exceeds snowfall, or by ice flow. Whether retreat occurs in marine or terrestrial sectors can affect the rate at which mass is lost and therefore the rates at which the ice sheet contributes to sea level change. Understanding the style of past ice sheet retreat is therefore critical to understanding possible rates of future sea level rise (DeConto and Pollard, 2016; Rintoul et al., 2018; Dowdeswell et al., 2020; Golledge, 2020).

Our current understanding of the formation and subsequent waxing and waning of the Antarctic Ice Sheet on millionyear timescales is largely based on marine sediment records recovered over the past 50 years through scientific ocean drilling (e.g., Kennett and Shackleton, 1976; Barker et al., 1999; Expedition 318 Scientists, 2010). A recently published review in Oceanography focused on how scientific ocean drilling of marine sedimentary records from the Antarctic continental margin has revolutionized understanding of the past behavior of the Antarctic Ice Sheet (Escutia et al., 2019). The ice proximal records discussed provide critical data in support of far-field records, which track the pacing of ice sheet change through changes in global ice volume and sea level, and also provide information on the climate drivers that caused these changes (e.g., Littler et al., 2019).

Although Antarctica was partially glaciated during intervals of the Eocene, with glaciation in the high Gamburtsev Mountains (Rose et al., 2013) and glaciers reaching the coast during cooler intervals (Gulick et al., 2017), the onset of continental-sized glaciation occurred during the earliest Oligocene (Miller et al, 1991; Zachos et al., 1992). Immediately after the Eocene-Oligocene boundary, 32.8 million years ago, a continentalscale ice sheet reached the coast of Antarctica (Stocchi et al., 2013; Galeotti et al., 2016). Throughout the Oligocene and into the early Miocene, ice advanced and retreated across the expanding con- 

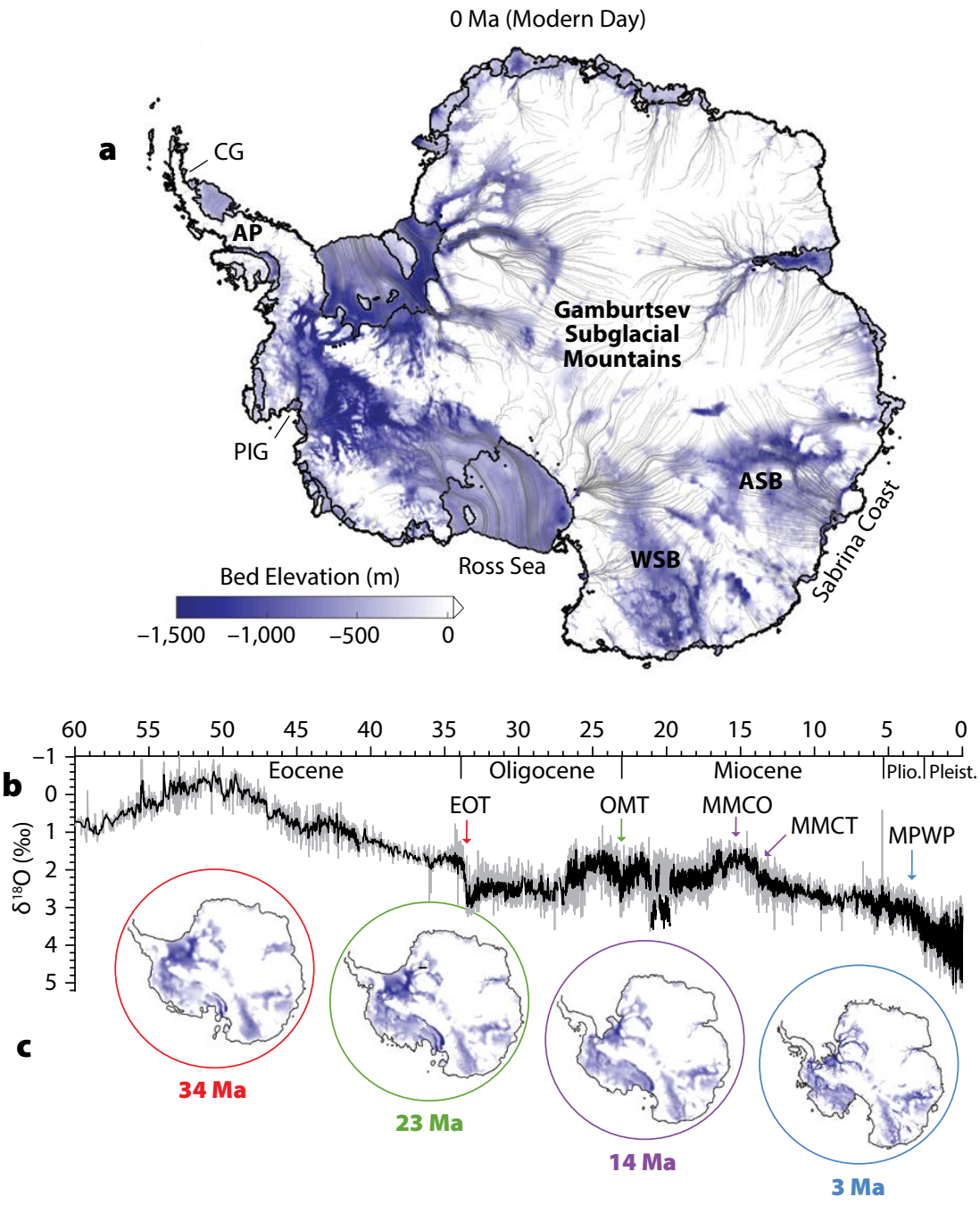

d $\quad\|\|\|\|\|\|\|\|\|\|\|\|||||||||||||$ Drake Passage opening, widening Stronger obliquity sensitivity,
increasing ice-ocean interaction

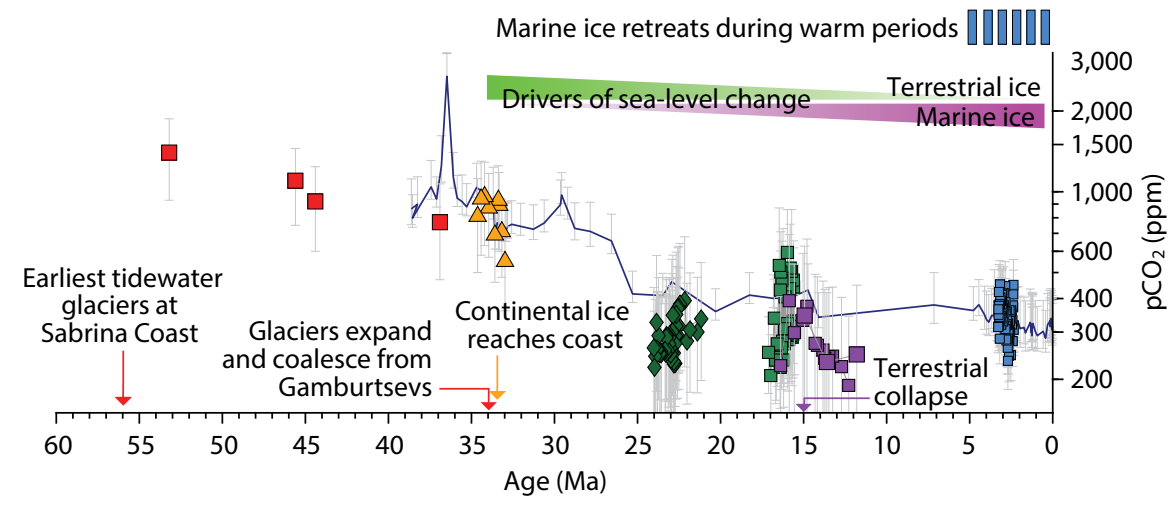

FIGURE 1. (a) Present-day Antarctica. Blue areas indicate marine ice, with topography currently below sea level, and white areas indicate terrestrial ice, grounded on topography above sea level. The black line is the present-day grounding line, the transition between grounded and floating ice. Gray flowlines indicate direction of surface ice flow from an ice sheet model simulation. AP = Antarctic Peninsula. ASB = Aurora Subglacial Basin. CG = Crane Glacier. PIG = Pine Island Glacier. WSB = Wilkes Subglacial Basin. (b) The composite oxygen isotope record from deep-sea foraminifera reveals the general history of the evolution of the Antarctic Ice Sheet, with higher values for increasing ice volume (Zachos et al., 2008). EOT = Eocene-Oligocene transition. OMT = OligoceneMiocene transition. $\mathrm{MMCO}=$ Mid-Miocene climatic optimum. $\mathrm{MMCT}=$ Middle Miocene climate transition. MPWP = Mid-Pliocene warm period. (c) Reconstructions of past marine (blue) and terrestrial (white) ice distribution on Antarctica for different time intervals (Paxman et al., 2019). (d) Composite of selected marine-based proxy $\mathrm{CO}_{2}$ reconstructions (Pearson et al., 2009; Foster et al., 2012; Zhang et al., 2013; Greenop et al., 2014, 2019; Martínez-Botí et al., 2015; Anagnostou et al., 2016). tinental shelf, but the magnitude of these oscillations is still subject to debate (McKay et al., 2016; De Vleeschouwer et al., 2017). Although not a direct measure of ice volume, far-field reconstructions based on oxygen isotope records from benthic foraminifera suggest cycles similar in magnitude to that of modern day Antarctic Ice Sheet volume (de Boer et al., 2010; Liebrand et al., 2017; Miller et al., 2020). The pacing of this early Antarctic Ice Sheet gradually shifted to a stronger sensitivity to obliquity (Earth's axial tilt) toward the mid and then late Miocene, as there was increased iceocean interaction (Levy et al., 2019). The ice sheet retreated substantially during the middle Miocene as atmospheric and ocean temperatures increased, and in this warmer and wetter climate, woody plants grew on the Antarctic coast (Warny et al., 2009; Lear et al., 2010; Feakins et al., 2012; Levy et al., 2016; Pierce et al., 2017; Sangiorgi et al., 2018). Immediately following this period, across the middle Miocene climate transition ( $\sim 14$ million years ago), the climate cooled and the ice sheet expanded and became more stable (Shevenell et al., 2004, 2008; Holbourn et al., 2005; Lewis et al., 2008). In the more recent geologic past, the Antarctic Ice Sheet likely retreated during warm intervals of the mid-Pliocene and during some of the warmest interglacials of the late Pleistocene, although this ice was likely sourced only from the marine sectors (Cook et al., 2013; Shakun et al., 2018; Wilson et al., 2018). High sea levels during the last interglacial are often interpreted as evidence for retreat of the Antarctic Ice Sheet, in particular, marine sectors of the West Antarctic Ice Sheet (Dutton et al., 2015; Rohling et al., 2019); however, direct evidence for the loss of the West Antarctic Ice Sheet during the last interglacial is still lacking (e.g., Turney et al., 2020). Note that aspects of this overview are disputednotably, the magnitude of past Antarctic Ice Sheet retreat has generated many vigorous debates (e.g., Barrett, 2013).

Here, we focus on the separate chal- 
lenges of simulating retreat of the marine and terrestrial sectors of the ice sheet by drawing on two intervals: (1) the middle Miocene, an interval that occurred $\sim 15$ million years ago, when atmospheric $\mathrm{CO}_{2}$ concentrations were similar to those projected for the coming decades under intermediate emissions pathways (Foster et al., 2012), and (2) the mid-Pliocene, an interval that occurred $\sim 3$ million years ago and likely the last time that atmospheric $\mathrm{CO}_{2}$ concentrations were as high as they are today (Cook et al., 2013; Martínez-Botí et al., 2015; Shakun et al., 2018). There is evidence for retreat of the terrestrial Antarctic Ice Sheet during the middle Miocene (e.g., Miller et al., 2020), and it is likely that there was retreat of the marine Antarctic Ice Sheet during the mid-Pliocene (Cook et al., 2013; Shakun et al., 2018; Dumitru et al., 2019; Grant et al., 2019). Note that in the rest of this paper, we purposely avoid distinction between the East and West Antarctic Ice Sheets, both of which contain terrestrial and marine sectors.

\section{TERRESTRIAL ICE SHEET}

\section{RETREAT: COMPLETE COLLAPSE OF THE ANTARCTIC ICE SHEET DURING THE MIDDLE MIOCENE?}

Records from around the Antarctic margin (Levy et al., 2016; Gulick et al., 2017; Pierce et al., 2017) and from far-field sea level and ice volume estimates (Shevenell et al., 2008; Miller et al., 2020) support retreat of the Antarctic Ice Sheet during the warm middle Miocene. The change in ice mass led to sea level change on the order of $\sim 60 \mathrm{~m}$ (Kominz et al., 2008; John et al., 2011) and fluctuations in the oxygen isotope composition of seawater, an estimate of ice volume, of $\sim 0.5 \%$ (Lear et al., 2010). These conditions would have required major retreat of the terrestrialbased ice sheet through surface meltingpossibly complete collapse of the ice sheet (Pekar and DeConto, 2006; Miller et al., 2020). However, simulating this retreat with coupled climate and ice sheet models with boundary conditions appropriate for the middle Miocene has been chal- lenging (Pollard and DeConto, 2005). The key middle-Miocene differences in boundary conditions that impact the ice sheets are differences in astronomical parameters, paleogeography (although these differences are relatively small compared with modern), and greenhouse gas concentrations. To generate widespread surface melting and retreat of the terrestrial Antarctic Ice Sheet with global circulation model (GCM)-forced ice sheet models requires a much larger increase in atmospheric $\mathrm{CO}_{2}$ than can be reconstructed from proxy records (Greenop et al., 2014).

The growth of the Antarctic Ice Sheet cooled the Antarctic continent's climate. Principally, increased albedo reflected more sunlight, and the atmospheric lapse rate led to cooling of the ice surface as the elevation of the growing ice sheet increased (Huybrechts, 1993). These strong positive feedbacks mean that simulating retreat of the Antarctic Ice Sheet requires a magnitude of warming that is inconsistent with proxy reconstructions of atmospheric $\mathrm{CO}_{2}$ during the middle Miocene (Pollard and DeConto, 2005; Langebroek et al., 2009). Although simulations of the onset of Antarctic glaciation are largely consistent with proxy reconstructions (DeConto and Pollard, 2003; Pearson et al., 2009), the simulated deglacial $\mathrm{CO}_{2}$ threshold is much higher than indicated by proxy records and generally outside the error range of these reconstructions (Foster et al., 2012; Foster and Rohling, 2013; shown in red on Figure 2). Following its inception, the simulated Antarctic Ice Sheet is therefore much more stable than the geologic record suggests. This is a fundamental problem because models that cannot capture past collapse will be conservative with respect to projections of future sea level change. Proposed solutions to this conundrum have targeted (a) the proxy records, for example, $\mathrm{CO}_{2}$ was higher than thought in the middle Miocene (Goldner et al., 2014), or we have been misinterpreting ice volume proxies; (b) climate and ice sheet mod-

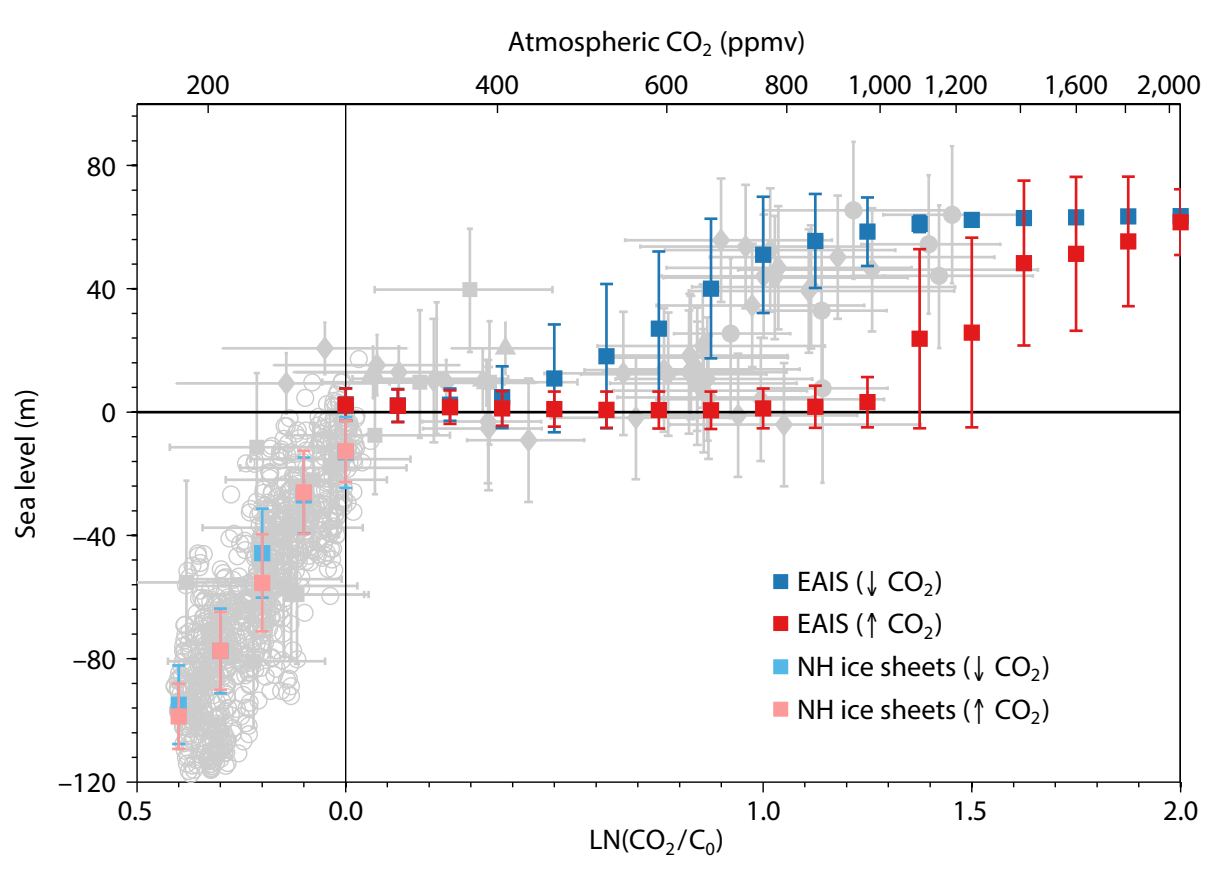

FIGURE 2. Reconstruction of regional sea level against proxy $\mathrm{CO}_{2}$ for the past 40 million years in gray (Foster and Rohling, 2013, and references therein). Sea level reconstructions are based on a variety of sources and may have local tectonic effects; as such, they should be viewed as relative sea level changes. The red and blue symbols are ice sheet model simulations of the East Antarctic Ice Sheet (EAIS) and Northern Hemisphere ( $\mathrm{NH}$ ) ice sheets; blue indicates a decrease in atmospheric $\mathrm{CO}_{2}$ and red an increase in atmospheric $\mathrm{CO}_{2}$. The error bars represent the binning of a perturbed parameter ensemble of simulations. Note that these ice sheet model simulations lack marine ice sheet physics. 
els simulating an overly stable ice sheet (Pollard and DeConto, 2005; Langebroek et al., 2009); (c) a missing forcing, for example, a larger role of changes in ocean gateways and changes in paleogeography; or (d) some combination of these effects (e.g., Langebroek et al., 2009; Gasson et al., 2016b; Stap et al., 2019).

The large ice volume changes in the Miocene Climate Optimum are based on assumptions inherent to our understanding of the oxygen isotope composition of benthic foraminifera, which provides a record of both global ice volume and deep ocean temperature that must be deconvolved (Shackleton, 1967). Multiple approaches have been used to extract ice volume from the benthic oxygen isotope records, including using an independent temperature proxy (e.g., Shevenell et al., 2008; Lear et al., 2010), estimating ice volume to temperature partitioning (e.g., Liebrand et al., 2017), and inverse modeling (de Boer et al., 2010). Langebroek et al. (2010) noted that producing an accurate ice volume record also requires knowledge of the changes in oxygen isotope composition of the ice sheets through time. Indeed, such changes, which are caused by changes in atmospheric moisture transport and ice sheet height, could lead to an overestimation of past ice volume changes (Winnick and Caves, 2015). Reconstructions that do not take this process into account (e.g., Miller et al., 2020) should be viewed with caution. Similarly, sea level reconstructions from passive continental margins may also contain signals that are caused by mantle dynamic topography rather than eustasy caused by the waxing and waning of the ice sheets (Moucha et al., 2008).

Alternatively, if ice-proximal reconstructions of past ice sheet extent and past estimates of ice volume change are deemed reliable, and sea level did rise and fall by as much as $60 \mathrm{~m}$, then it is important to determine why current climate and ice sheet models are unable to produce this level of dynamism. Improved representation of ice sheet-climate feedbacks is one way of increasing ice sheet dyna- mism. Recent simulations that used an asynchronous ice sheet-climate coupling and that accounted for changes in ice sheet oxygen isotopes are a better match to benthic oxygen isotope estimates and records from the Antarctic margin (Gasson et al., 2016b; Levy et al., 2016), although they still predict a smaller sea level amplitude $(\sim 35 \mathrm{~m})$ than some sea level reconstructions (John et al., 2011; Miller et al., 2020). These simulations also include a mechanism for the structural failure of marine ice cliffs, discussed in more detail below.

The problem of simulating the retreat of terrestrial Antarctic ice is linked to another well-studied model-data disagreement in paleoclimate (Barron, 1983) - the reduced temperature gradient between the poles and the tropics during warm periods and, in particular, the strong polar warming shown by temperature proxies that is generally not matched in coupled ocean-atmosphere model simulations (cf. Huber and Caballero, 2011; Sagoo et al., 2013). Successive generations of GCMs have failed to capture this polar amplification (Lunt et al., 2012); the models that come closest to the proxies require unrealistically high $\mathrm{CO}_{2}$ forcing or model tuning. However, recent results from the latest generation of GCMs show promise for resolving this long-standing problem (Lunt et al., 2020).

The reduced equator-to-pole temperature gradient is perhaps best associated with the early Eocene, a warm interval when there were no ice sheets on Antarctica. Improvements to climate model cloud physics has led to enhanced Eocene warming at high latitudes through shortwave cloud feedbacks; these results are closer to proxy-derived temperature reconstructions at high latitudes (Zhu et al., 2019), although they may now be too warm in the tropics (Zhu et al., 2020). The new generation of climate models includes a subset of models that have much higher climate sensitivity (the amount of warming for a doubling of atmospheric $\mathrm{CO}_{2}$ ) than earlier models, in part because of developments in the representation of cloud physics (Zelinka et al., 2020). Paleoclimate data are a key test as to whether this higher climate sensitivity is plausible or not (Zhu et al., 2020).

It remains to be seen how the presence of significant ice on Antarctica affects polar amplification and shortwave cloud feedbacks in this new generation of climate models, something missing in studies of the early Eocene. Another modeling target is the Miocene. The advantage of focusing on the Miocene is that it is an interval during which the global continental configuration was fairly similar to today-importantly including the presence of ice on Antarctica (Goldner et al., 2014). It is possible that with greater polar amplification there will be enhanced surface melting and a strong surface mass balance feedback as the ice elevation decreases and melt accelerates at a lower atmospheric $\mathrm{CO}_{2}$ threshold than previously simulated. Idealized simulations have shown that the ice sheet hysteresis problem can be reduced with an increase in polar amplification, although a mechanism to drive this increase is lacking (Langebroek et al., 2009). It is therefore an exciting time to reassess the longstanding problem of simulating past changes to the terrestrial sectors of the Antarctic Ice Sheet.

There is still much work to be done to understand how the Antarctic Ice Sheet responded to past climate changes and, in particular, what drove past retreat of terrestrial ice. Advances will come from a combined approach targeting both farfield and ice-proximal data (Kennicutt et al., 2015). Clearly defined modeling targets, such as quantitative icevolume estimates or locations with evidence for meltwater, are incredibly useful (e.g., Lewis et al., 2006; Warny et al., 2009; Mudelsee et al., 2014; Gulick et al., 2017). The recent retrieval of new ice-proximal records from three sectors of Antarctica as part of the International Ocean Discovery Program are already providing some of these key records (Escutia et al., 2019; McKay et al., 2019). 
If the retreat of the terrestrial Antarctic Ice Sheet through surface melting did occur under modest atmospheric $\mathrm{CO}_{2}$ concentrations, we may be forced to reassess long-term future projections (on millennial timescales) of the response of the ice sheet to anthropogenic warming (e.g., Winkelmann et al., 2015).

\section{MARINE ICE SHEET RETREAT: ICE SHEET RESPONSE TO MID-PLIOCENE WARMTH}

During the middle Miocene Climate Transition, the climate cooled and the terrestrial Antarctic Ice Sheet became more stable (Kennett, 1977; Shevenell et al., 2004). This scenario is supported by cosmogenic isotope data from the Ross Sea suggesting that for the past 8 million years there has been no retreat of the terrestrial Antarctic Ice Sheet (at least of the sectors draining through the Ross Sea) that would expose land (Shakun et al., 2018). Any ice loss that raised sea levels during this interval would have come from the marine sectors of Antarctica, such as the West Antarctic Ice Sheet, the large basins of East Antarctica, and the Wilkes and Aurora subglacial basins (shown in Figure 1). As mentioned previously, these sectors contain enough ice to raise global sea level by $\sim 23 \mathrm{~m}$. This figure is similar to some estimates of sea level rise during the mid-Pliocene warm interval (3.0-3.2 million years ago; Miller et al., 2012), the last time atmospheric $\mathrm{CO}_{2}$ concentrations exceeded $400 \mathrm{ppm}$ (Martínez-Botí et al., 2015). The sea level maximum during the mid-Pliocene remains poorly constrained, with large uncertainties (Dutton et al., 2015). However, there is physical evidence for substantial ice retreat in the marine sectors of East Antarctica (Cook et al., 2013) as well as far-field evidence for $>10 \mathrm{~m}$ sea level fluctuations (Dumitru et al., 2019; Grant et al., 2019).

Marine ice sheets have long been of interest because of their potential vulnerability to ocean warming (Mercer, 1978). A grounded ice sheet and a floating ice shelf connect at the grounding line. The rate of ice flow from grounded to floating ice is very sensitive to the ice thickness at the grounding line. Analytical solutions suggest that the ice flow across the grounding line increases highly nonlinearly in response to increases in the grounding line ice thickness. In places where the ice sheet bed is on a slope that deepens upstream of the grounding line, including in the large marine basins mentioned above, the geometry of the ice sheet creates the potential for a runaway retreat (Schoof, 2007). As the grounding line retreats backward across this deepening bed, a positive feedback called the "Marine Ice Sheet Instability" (MISI) develops because of the strong increase in ice flow (Mercer, 1978). Restabilization only occurs when the profile of the bed topography changes and the grounding line retreats to sufficiently shallow topography (Figure 3a; Alley and Joughin, 2012). The ability for ice sheet models to correctly simulate the MISI is a key test conducted in inter-model comparison projects (Cornford et al., 2020). The mid-Pliocene warm interval could be considered a real-world test of marine ice sheet behavior, with the caveats that the forcing and the response both have uncertainties (DeConto and Pollard, 2016; Dolan et al., 2018).

Similar to the problem of simulating retreat of the terrestrial Antarctic Ice Sheet, model simulations have largely failed to reproduce retreat in marine sectors of the ice sheet during the Pliocene. This is true for a range of ice sheet models (although they are all relatively lowresolution models with simplified physics) and climate model forcing (de Boer et al., 2015; Dolan et al., 2018). The only models that have successfully simulated retreat have required additional processes that enhance losses from ocean melting (Mengel et al., 2016; Golledge et al., 2017), surface melting (Hill et al., 2007), or calving (Pollard et al., 2015). We next review each of these approaches and their potential limitations.

Golledge et al. (2017) simulated retreat of the Antarctic Ice Sheet by $\sim 9 \mathrm{~m}$ during the early Pliocene. This model includes a parameterization that affects ocean melting at the grounding line. The "sub-grid melt parameterization" applies a reduced ocean melt rate proportional to the fraction of model cells that are floating versus grounded (Figure 3c). This is controversial because it applies an ice shelf melt rate, albeit reduced, to all parts of the cell, including the grounded fraction that is upstream of the grounding line. This parameterization is used to overcome the limitations of using lowresolution ice sheet models in order to perform long-duration simulations that can be compared with paleoclimate data. It also builds on the increasing recognition that ice-ocean interactions occur over a broader grounding "zone" rather than a fixed grounding line. Similar subgrid schemes are used to calculate the ice flux across the grounding line (Pollard and DeConto, 2009). However, tests of the sub-grid melt parameterization with higher-resolution models that are able to resolve the grounding line in more detail show that this scheme may overestimate mass loss from ice shelf melting (Seroussi and Morlighem, 2018). The sensitivity of ice sheet simulations to the inclusion of this parameterization can be largethe Antarctic Ice Sheet sea level projections for the emissions scenario RCP8.5 of Golledge et al. (2015) vary from $1.6 \mathrm{~m}$ to $3.0 \mathrm{~m}$ by 2300 , with and without sub-grid melt.

Hill et al. (2007) forced an ice sheet model with constant climate forcing from a climate model run with an already partially retreated Antarctic Ice Sheet. This simulation resulted in retreat of the Antarctic Ice Sheet equivalent to $\sim 9 \mathrm{~m}$ of sea level, driven by surface melting. This study is one example of a common approach to ice sheet modeling studies in which the ice sheet model and the climate model are not directly coupled. Therefore, the global surface topography, including the ice sheets, is prescribed in the climate model and large differences can develop between ice sheet extent in the ice sheet model and in the climate 
(a) Marine Ice Sheet Instability (MISI)

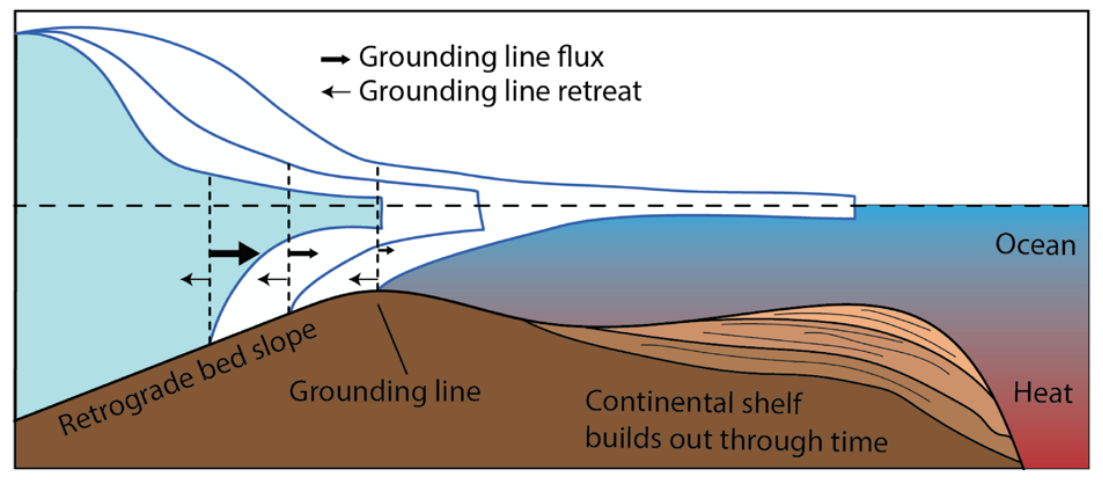

(b) Marine Ice Cliff Instability (MICl)

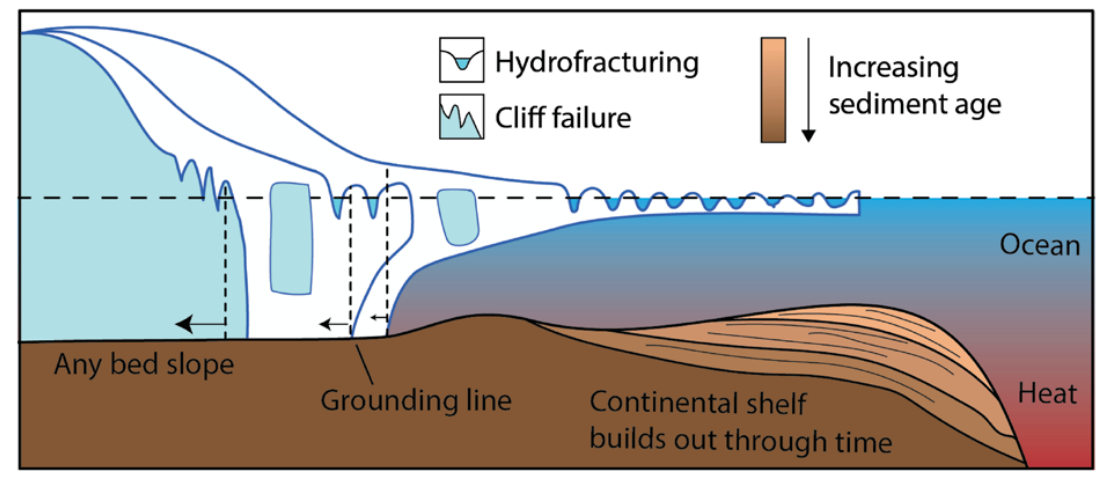

(c) Sub-Grid Grounding Line Parameterization

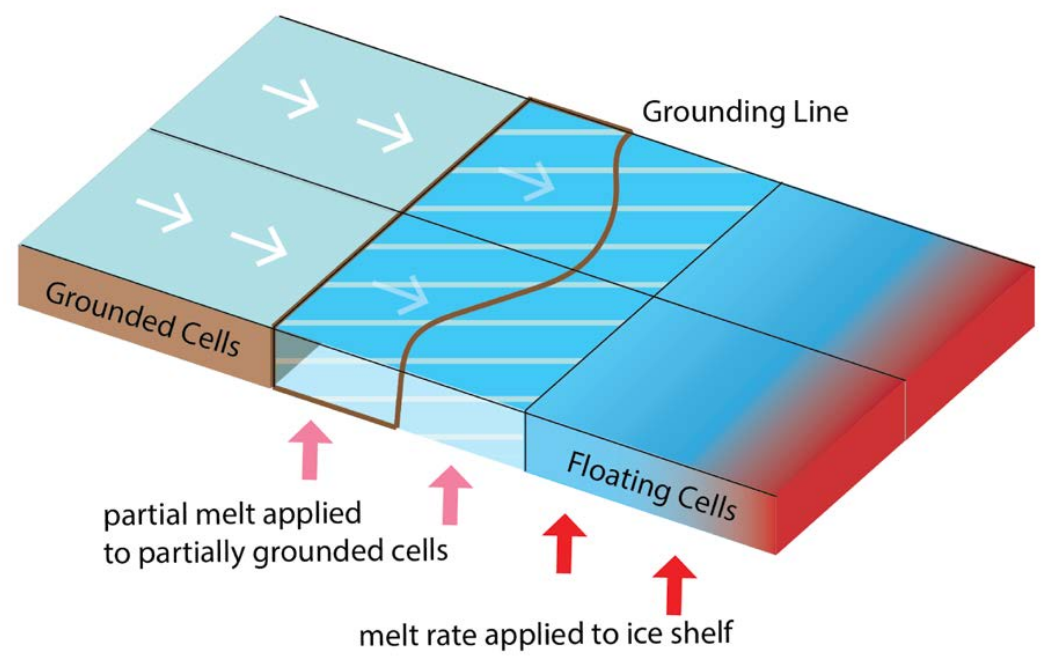

FIGURE 3. Schematics of processes discussed in the text. (a) Marine ice sheet instability on a retrograde slope. (b) Marine ice cliff instability (DeConto and Pollard, 2016). (c) The sub-grid grounding line melt parameterization (adapted from Seroussi and Morlighem, 2018). model. Any feedbacks from the retreat of the ice sheet are applied to the climate forcing before the ice sheet has retreated. There is therefore concern that the experimental design led to this result. Indeed, tests of alternative climate model forcing, without a collapsed ice sheet, do not produce a similar magnitude of retreat (Dolan et al., 2018). Approaches to forcing ice sheet models are evolving as more attention is paid to direct or asynchronous climate coupling to capture feedbacks between the ice sheets, the ocean, and the atmosphere (e.g., Golledge et al., 2019).

Pollard et al. (2015) introduced a scheme for the structural failure of large marineterminating ice cliffs in combination with the hydrofracture of ice shelves. This scheme was based on earlier work of Bassis and Walker (2012) and is called "Marine Ice Cliff Instability" (MICI; DeConto and Pollard, 2016). Based on theoretical work, Pollard et al. (2015) introduced an upper limit for the height above water level that ice cliffs can reach. Beyond this limit, stresses exceed the strength of ice and there is brittle failure of the ice cliff. Ice cliffs can form when the buttressing ice shelves are rapidly removed. In the model, this is done using a scheme for hydrofracturing, which is caused by the rapid calving of ice shelves when meltwater and rain drain into surface crevasses. This process is similar to the disintegration of the Larsen B ice shelf, which occurred very rapidly (in $\sim 1$ month). Once an ice cliff fails, as long as the grounded ice is thick enough to keep failing, a runaway retreat can occur (Figure $3 b$ ).

There are many uncertainties associated with MICI, including the potential rate of ice cliff collapse, what is the failure threshold for subaerial ice cliffs, and whether ice shelves can be removed fast enough to generate sheer cliffs before ice flows into a more stable state (Bell et al., 2017; Clerc et al., 2019; Parizek et al., 2019; Robel and Banwell, 2019). Understanding the potential significance of MICI is limited by a lack of observations because there are only a few locations where MICI-like behavior occurs. Most Antarctic glaciers that have bedrock geometry favorable for MICI are currently protected by ice shelves, with the possible exception of Crane Glacier. In Greenland, the calving fronts of Helheim and Jakobshavn Isbræ Glaciers terminate with subaerial ice cliffs that reach $\sim 100 \mathrm{~m}$ in height (Meredith et al., 2019). Observation of 
calving events at these glaciers is ongoing to improve understanding of MICI. However, these glaciers are situated in confined valleys and are not perfect analogues to the much wider calving fronts of Antarctica, such as that of Thwaites Glacier (Parizek et al., 2019). This active area of research has been stimulated in part by the rapid rates and high magnitudes of future sea level change in simulations that include these processes-up to $\sim 8 \mathrm{~m}$ by 2300 under emission scenario RCP8.5 (DeConto and Pollard, 2016).

An alternative take on the Pliocene sea level problem is that retreat was confined to the marine sectors of the West Antarctic Ice Sheet. This scenario would be consistent with model predictions that do not include MICI (de Boer et al., 2015). When the uncertainties regarding Pliocene sea level estimates are interrogated more closely, this scenario is a possibility for at least some methods (Winnick and Caves, 2015; Gasson et al., 2016a). Indeed, Edwards et al. (2019) suggest that the simulations of DeConto and Pollard (2016) that do not include MICI and ice shelf hydrofracture are consistent with the lowest bounds on Pliocene sea level. The lack of consensus on the Pliocene sea level maximum means that this warm climate interval is currently of debated utility in discriminating between different ice sheet physics (Raymo et al., 2018). This situation was improved recently by the publication of two new studies on Pliocene sea level, one concerning overgrowths on speleothems measured in caves on Mallorca (Dumitru et al., 2019) and another the amplitude of glacialinterglacial sea level cycles based on grain-size analysis of cores drilled in New Zealand (Grant et al., 2019). Both of these support retreat of marine ice throughout Antarctica during the Pliocene. However, the uncertainties are still large and may not alter the conclusions of Edwards et al. (2019). Better constrained sea level estimates of the mid-Pliocene warm period remain critically important to resolving the debate over the stability of Antarctica's marine ice.

\section{OUTLOOK AND CONCLUSIONS}

We have described the broad challenges that currently exist in simulating the response of the Antarctic Ice Sheet to climate changes in the geologic past. In sum, proxy records suggest greater ice sheet instability than is often captured by ice sheet modeling studies (Pollard and DeConto, 2005; de Boer et al., 2015). Maintaining a critical view of both data- and model-based histories of the Antarctic Ice Sheet is critical for connecting, and ultimately bridging the two related but often isolated disciplinary communities. We have focused on the separate challenges of simulating retreat of the "terrestrial" and "marine" sectors of the ice sheet and the different styles and mechanisms of ice sheet retreat during the warm intervals of the middle Miocene and the mid-Pliocene. These intervals were chosen as they arguably best characterize the model-data mismatch and provide clear examples of how new modeling approaches are probing longstanding mysteries.

Many other avenues not mentioned in this paper should be further explored by the next generation of ice sheet modelers. The role of opening and widening ocean gateways, in particular Drake Passage, in the inception, fluctuations, and persistence of ice on Antarctica remains debated (Figure 1; Kennett, 1977; Goldner et al. 2014). Coupling of ice sheet and solid Earth models demonstrates how and why different sectors of Antarctica may have become more or less prone to retreat through time (Austermann et al., 2015; Whitehouse et al., 2019). Ice sheets exert local influences on sea level and the surrounding ocean that can affect their stability, and these processes have only recently been included in ice sheet modeling studies (Golledge et al., 2019). Novel observations collected by marine mammals near calving fronts (e.g., Treasure et al., 2017) and autonomous vehicles under floating ice shelves (e.g., Spears et al., 2016) are challenging model parameterizations of the interactions between warm ocean water and the ice sheet. Such techniques will be critical for understanding active subglacial meltwater features (e.g., Drews et al., 2017) that may extend over a kilometers-wide "grounding zone" beneath the grounded ice sheet (e.g., Christianson et al., 2016). As observations become more detailed, we also find small-scale geological features that can be directly linked to ice sheet processes and thus offer tantalizing targets for models-for example, the observation of corrugation ridges in Pine Island Trough (Wise et al., 2017), "ladders and rungs" on the seafloor of the eastern Antarctic Peninsula (Dowdeswell et al., 2020), and paleo-meltwater channels in the Ross Sea region (Lewis et al., 2006; Simkins et al., 2017) and along the Sabrina Coast (Gulick et al., 2017). In these realms and others, the convergence of geologic data, new observations, and continental-scale models offers many productive paths forward for understanding past fluctuations of the Antarctic Ice Sheet. In further addressing the data-model inconsistencies highlighted in this paper, new developments in ice sheet models may reveal still more mysteries. Close collaboration between data- and modelfocused communities will remain critical for moving forward. @

\section{REFERENCES}

Alley, R.B., and I. Joughin. 2012. Modeling ice-sheet flow. Science 336(6081):551-552, https://doi.org/ 10.1126/science.1220530.

Alley, R.B., S. Anandakrishnan, K. Christianson, H.J. Horgan, A. Muto, B.R. Parizek, D. Pollard, and R.T. Walker. 2015. Oceanic forcing of icesheet retreat: West Antarctica and more. Annual Review of Earth and Planetary Sciences 43(1):207-231, https://doi.org/10.1146/ annurev-earth-060614-105344.

Anagnostou, E., E.H. John, K.M. Edgar, G.L. Foster, A. Ridgwell, G.N. Inglis, R.D. Pancost, D.J. Lunt, and P.N. Pearson. 2016. Changing atmospheric $\mathrm{CO}_{2}$ concentration was the primary driver of early Cenozoic climate. Nature 533(7603):380-384, https://doi.org/10.1038/nature17423.

Austermann, J., D. Pollard, J.X. Mitrovica, R. Moucha, A.M. Forte, R.M. DeConto, D.B. Rowley, and M.E. Raymo. 2015. The impact of dynamic topography change on Antarctic Ice Sheet stability during the mid-Pliocene warm period. Geology 43(10):927-930, https://doi.org/10.1130/ G36988.1.

Banwell, A.F., I.C. Willis, G.J. Macdonald, B. Goodsell, and D.R. MacAyeal. 2019. Direct measurements of ice-shelf flexure caused by surface meltwater ponding and drainage. Nature Communications 10(1):730, https://doi.org/10.1038/ s41467-019-08522-5. 
Barker, P.F., P.J. Barrett, A.K. Cooper, and P. Huybrechts. 1999. Antarctic glacial history from numerical models and continental margin sediments. Palaeogeography, Palaeoclimatology, Palaeoecology 150(3-4):247-267, https://doi.org/ 10.1016/S0031-0182(98)00224-7.

Barrett, P. 2013. Resolving views on Antarctic Neogene glacial history - the Sirius debate. Earth and Environmental Science Transactions of the Royal Society of Edinburgh 104(1):31-53, https://doi.org/10.1017/S175569101300008X.

Barron, E.J. 1983. A warm, equable Cretaceous: The nature of the problem. Earth Science Reviews 19(4):305-338, https://doi.org/ 10.1016/0012-8252(83)90001-6.

Bart, P.J. 2003. Were West Antarctic Ice Sheet grounding events in the Ross Sea a consequence of East Antarctic Ice Sheet expansion during the middle Miocene? Earth and Planetary Science Letters 216(1-2):93-107, https://doi.org/10.1016/ S0012-821X(03)00509-0.

Bassis, J.N., and C.C. Walker. 2012. Upper and lower limits on the stability of calving glaciers from the yield strength envelope of ice. Proceedings of the Royal Society A 468(2140):913-931, https://doi.org/ 10.1098/rspa.2011.0422.

Bell, R.E., W. Chu, J. Kingslake, I. Das, M. Tedesco, K.J. Tinto, C.J. Zappa, M. Frezzotti, A. Boghosian, and W.S. Lee. 2017. Antarctic ice shelf potentially stabilized by export of meltwater in surface river. Nature 544(7650):344-348, https://doi.org/10.1038/ nature22048.

Bintanja, R., G.J. Van Oldenborgh, S.S. Drijfhout, B. Wouters, and C.A. Katsman. 2013. Important role for ocean warming and increased ice-shelf melt in Antarctic sea-ice expansion. Nature Geoscience 6(5):376-379, https://doi.org/10.1038/ ngeo1767.

Christianson, K., R.W. Jacobel, H.J. Horgan, R.B. Alley, S. Anandakrishnan, D.M. Holland, and K.J. DallaSanta. 2016. Basal conditions at the grounding zone of Whillans Ice Stream, West Antarctica, from ice-penetrating radar. Journal of Geophysical Research 121(11):1,954-1,983, https://doi.org/10.1002/2015JF003806.

Clerc, F., B.M. Minchew, and M.D. Behn. 2019 Marine ice cliff instability mitigated by slow removal of ice shelves. Geophysical Research Letters 46:12,108-12,116, https://doi.org/10.1029/ 2019 GL084183.

Colleoni, F., L. De Santis, C.S. Siddoway, A. Bergamasco, N.R. Golledge, G. Lohmann, S. Passchier, and M.J. Siegert. 2018. Spatiotemporal variability of processes across Antarctic ice-bed-ocean interfaces. Nature Communications 9(1):2289, https://doi.org/10.1038/ s41467-018-04583-0.

Cook, C.P., T. Van De Flierdt, T. Williams, S.R. Hemming, M. Iwai, M. Kobayashi, F.J. JimenezEspejo, C. Escutia, J.J. González, B.-K. Khim, and others. 2013. Dynamic behaviour of the East Antarctic ice sheet during Pliocene warmth. Nature Geoscience 6(9):765-769, https://doi.org/10.1038/ ngeo1889.

Cornford, S., H. Seroussi, X. Asay-Davis, and G.H. Gudmundsson. 2020. Results of the third Marine Ice Sheet Model Intercomparison Project (MISMIP+). Cryosphere Discussions, https://doi.org/ 10.5194/tc-2019-326.

de Boer, B., R.S.W. van de Wal, R. Bintanja, L.J. Lourens, and E. Tuenter. 2010. Cenozoic global ice-volume and temperature simulations with 1-D ice-sheet models forced by benthic $\delta^{18} \mathrm{O}$ records. Annals of Glaciology 51(55):23-33, https://doi.org/ 10.3189/172756410791392736.

de Boer, B., A.M. Dolan, J. Bernales, E. Gasson, H. Goelzer, N.R. Golledge, J. Sutter, P. Huybrechts, G. Lohmann, I. Rogozhina, and others. 2015. Simulating the Antarctic ice sheet in the latePliocene warm period: PLISMIP-ANT, an icesheet model intercomparison project. The Cryosphere 9:881-903, https://doi.org/10.5194/ tc-9-881-2015.
DeConto, R., and D. Pollard. 2003. Rapid Cenozoic glaciation of Antarctica induced by declining atmospheric $\mathrm{CO}_{2}$. Nature 421:245-249, https://doi.org/ 10.1038/nature01290.

DeConto, R., D. Pollard, and D. Harwood. 2007. Sea ice feedback and Cenozoic evolution of Antarctic climate and ice sheets. Paleoceanography 22(3), https://doi.org/10.1029/2006PA001350.

DeConto, R., and D. Pollard. 2016. Contribution of Antarctica to past and future sea-level rise. Nature 531(7596):591-597, https://doi.org/10.1038/ nature17145.

De Vleeschouwer, D., M. Vahlenkamp, M. Crucifix, and H. Pälike. 2017. Alternating Southern and Northern Hemisphere climate response to astronomical forcing during the past 35 m.y. Geology 45(4):375-378, https://doi.org/10.1130/G38663.1.

Dolan, A.M., B. de Boer, J. Bernales, D.J. Hill, and A.M. Haywood. 2018. High climate model dependency of Pliocene Antarctic ice-sheet predictions. Nature Communications 9:2799, https://doi.org/ 10.1038/s41467-018-05179-4

Dowdeswell, J.A., C.L. Batchelor, A. Montelli, D. Ottesen, F.D.W. Christie, E.K. Dowdeswell, and J. Evans. 2020. Delicate seafloor landforms reveal past Antarctic grounding-line retreat of kilometers per year. Science 368(6494):1,020-1,024 https://doi.org/10.1126/science.aaz3059.

Drews, R., F. Pattyn, I. Hewitt, F.S.L. Ng, S. Berger, K. Matsuoka, V. Helm, N. Bergeot, L. Favier, and N. Neckel. 2017. Actively evolving subglacial conduits and eskers initiate ice shelf channels at an Antarctic grounding line. Nature Communications 8:15228, https://doi.org/10.1038/ ncomms15228.

Dumitru, O.A., J. Austermann, V.J. Polyak, J.J. Fornós Y. Asmerom, J. Ginés, A. Genés, and B.P. Onac. 2019. Constraints on global mean sea level during Pliocene warmth. Nature 574(7777):233-236, https://doi.org/10.1038/s41586-019-1543-2.

Dutton, A., A.E. Carlson, A.J. Long, G.A. Milne, P.U. Clark, R. DeConto, B.P. Horton, S. Rahmstorf, and M.E. Raymo. 2015. Sea-level rise due to polar ice-sheet mass loss during past warm periods. Science 349(6244):aaa4019, https://doi.org/10.1126/ science.aaa4019.

Edwards, T.L., M.A. Brandon, G. Durand, N.R. Edwards, N.R. Golledge, P.B. Holden, I.J. Nias, A.J. Payne, C Ritz, and A. Wernecke. 2019. Revisiting Antarctic ice loss due to marine icecliff instability. Nature 566:58-64, https://doi.org/ 10.1038/s41586-019-0901-4.

Escutia, C., R.M. DeConto, R. Dunbar, L. De Santis, A. Shevenell, and T. Naish. 2019. Keeping an eye on Antarctic Ice Sheet stability. Oceanography 32(1):32-46, https://doi.org/ 10.5670/oceanog.2019.117.

Expedition 318 Scientists. 2010. Wilkes Land glacial history: Cenozoic East Antarctic Ice Sheet evolution from Wilkes Land margin sediments. Integrated Ocean Drilling Program Preliminary Report, volume 318, https://doi.org/10.2204/iodp.pr.318.2010.

Feakins, S.J., S. Warny, and J.E. Lee. 2012. Hydrologic cycling over Antarctica during the middle Miocene warming. Nature Geoscience 5:557-560, https://doi.org/10.1038/ngeo1498.

Foster, G.L., C.H. Lear, and J.W.B. Rae. 2012. The evolution of $\mathrm{pCO}_{2}$, ice volume and climate during the middle Miocene. Earth and Planetary Science Letters 341-344:243-254, https://doi.org/10.1016/ j.epsl.2012.06.007.

Foster, G.L., and E.J. Rohling. 2013. Relationship between sea level and climate forcing by $\mathrm{CO}_{2}$ on geological timescales. Proceedings of the National Academy of Sciences of the United States of America 110(4):1,029-1,214, https://doi.org/10.1073/ pnas.1216073110.

Fretwell, P., H.D. Pritchard, D.G. Vaughan, J.L. Bamber, N.E. Barrand, R. Bell, C. Bianchi, R.G. Bingham, D.D. Blankenship. G. Casassa, and others. 2013. Bedmap2: Improved ice bed, surface and thickness datasets for Antarctica. The Cryosphere 7(1):375-393, https://doi.org/10.5194/ tc-7-375-2013.
Fürst, J.J., G. Durand, F. Gillet-Chaulet, L. Tavard,

M. Rankl, M. Braun, and O. Gagliardini. 2016.

The safety band of Antarctic ice shelves. Nature Climate Change 6(5):479-482, https://doi.org/ 10.1038/nclimate2912.

Galeotti, S., R. DeConto, T. Naish, P. Stocchi, F. Florindo, M. Pagani, P. Barrett, S.M. Bohaty, L. Lanci, D. Pollard, and others. 2016. Antarctic Ice Sheet variability across the EoceneOligocene boundary climate transition. Science 352(6281):76-80, https://doi.org/10.1126/ science.aab0669.

Gasson, E., R.M. DeConto, and D. Pollard. 2016a. Modeling the oxygen isotope composition of the Antarctic ice sheet and its significance to Pliocene sea level. Geology 44(10):827-830, https://doi.org/ 10.1130/G38104.1.

Gasson, E., R.M. DeConto, D. Pollard, and R.H. Levy. 2016b. Dynamic Antarctic Ice Sheet during the early to mid-Miocene. Proceedings of the National Academy of Sciences of the United States of America 113(13):3,459-3,464, https://doi.org/ 10.1073/pnas.1516130113.

Goldner, A., N. Herold, and M. Huber. 2014. The challenge of simulating the warmth of the midMiocene climatic optimum in CESM1. Climate of the Past 10(2):523-536, https://doi.org/10.5194/ cp-10-523-2014.

Golledge, N.R. 2020. Long-term projections of sea-level rise from ice sheets. WIREs Climate Change 11(2):e634, https://doi.org/10.1002/wcc.634.

Golledge, N.R., D.E. Kowalewski, T.R. Naish, R.H. Levy, C.J. Fogwill, and E.G.W. Gasson. 2015. The multi-millennial Antarctic commitment to future sea-level rise. Nature 526(7573):421-425, https://doi.org/10.1038/nature15706.

Golledge, N.R., Z.A. Thomas, R.H. Levy,

E.G.W. Gasson, T.R. Naish, R.M. McKay, D.E. Kowalewski, and C.J. Fogwill. 2017. Antarctic climate and ice-sheet configuration during the early Pliocene interglacial at 4.23 Ma. Climate of the Past 13:959-975, https://doi.org/10.5194/ cp-13-959-2017.

Golledge, N.R., E.D. Keller, N. Gomez,

K.A. Naughten, J. Bernales, L.D. Trusel, and T.L. Edwards. 2019. Global environmental consequences of twenty-first-century ice-sheet melt. Nature 566(7742):65-72, https://doi.org/10.1038/ s41586-019-0889-9.

Grant, G.R., T.R. Naish, G.B. Dunbar, P. Stocchi, M.A. Kominz, P.J.J. Kamp, C.A. Tapia, R.M. McKay, R.H. Levy, and M.O. Petterson. 2019. The amplitude and origin of sea-level variability during the Pliocene epoch. Nature 574(7777):237-241, https://doi.org/10.1038/s41586-019-1619-z.

Greenop, R., G.L. Foster, P.A. Wilson, and C.H. Lear. 2014. Middle Miocene climate instability associated with high-amplitude $\mathrm{CO}_{2}$ variability. Paleoceanography and Paleoclimatology 29(9):845-853, https://doi.org/ 10.1002/2014PA002653.

Greenop, R., S.M. Sosdian, M.J. Henehan, P.A. Wilson, C.H. Lear, and G.L. Foster. 2019. Orbital forcing, ice volume, and $\mathrm{CO}_{2}$ across the OligoceneMiocene Transition. Paleoceanography and Paleoclimatology 34(3):316-328, https://doi.org/ 10.1029/2018PA003420.

Gulick, S.P.S., A.E. Shevenell, A. Montelli, R. Fernandez, C. Smith, S. Warny, S.M. Bohaty, C. Sjunneskog, A. Leventer, B. Frederick, and D.D. Blankenship. 2017. Initiation and longterm instability of the East Antarctic Ice Sheet. Nature 552(7684):225-229, https://doi.org/10.1038/ nature25026.

Hill, D., A. Haywood, R. Hindmarsh, and P. Valdes 2007. Characterising ice sheets during the mid Pliocene: Evidence from data and models. Pp. 517-538 in Deep Time Perspectives on Climate Change: Marrying the Signal from Computer Models and Biological Proxies. M. Williams, A. Haywood, F. Gregory, and D. Schmidt, eds, Geological Society of London. 
Holbourn, A., W. Kuhnt, M. Schulz, and H. Erlenkeuser. 2005. Impacts of orbital forcing and atmospheric carbon dioxide on Miocene ice-sheet expansion. Nature 438(7067):483-487, https://doi.org/10.1038/ nature 04123

Huber, M., and R. Caballero. 2011. The early Eocene equable climate problem revisited. Climate of the Past 7(2):603-633, https://doi.org/10.5194/ cp-7-603-2011.

Huybrechts, P. 1993. Glaciological modelling of the late Cenozoic East Antarctic Ice Sheet: Stability or dynamism? Geografiska Annaler: Series A, Physical Geography 75(4):221-228, https://doi.org/10.2307/ 521202.

John, C.M., G.D. Karner, E. Browning, R.M. Leckie, Z. Mateo, B. Carson, and C. Lowery. 2011. Timing and magnitude of Miocene eustasy derived from the mixed siliciclastic-carbonate stratigraphic record of the northeastern Australian margin. Earth and Planetary Science Letters 304(3-4):455-467, https://doi.org/10.1016/j.epsl.2011.02 013.

Kennett, J.P. 1977. Cenozoic evolution of Antarctic glaciation, the circum-Antarctic Ocean, and thei mpact on global paleoceanography. Journal of Geophysical Research 82(27):3,843-3,860, https://doi.org/10.1029/JC082i027p03843.

Kennett, J., and N. Shackleton. 1976. Oxygen isotopic evidence for the development of the psychrosphere 38 Myr ago. Nature 260(8):513-515, https://doi.org/10.1038/260513a0.

Kennicutt, M.C., S.L. Chown, J.J. Cassano, D. Liggett, L.S. Peck, R. Massom, S.R. Rintoul, J. Storey, D.G. Vaughan, T.J. Wilson, and others. 2015 A roadmap for Antarctic and Southern Ocean science for the next two decades and beyond. Antarctic Science 27(1):3-18, https://doi.org/10.1017/ S0954102014000674.

Kingslake, J., J.C. Ely, I. Das, and R.E. Bell. 2017. Widespread movement of meltwater onto and across Antarctic ice shelves. Nature 544:349-352, https://doi.org/10.1038/nature22049.

Kominz, M.A., J.V. Browning, K.G. Miller, P.J. Sugarman, S. Mizintseva, and C.R. Scotese 2008. Late Cretaceous to Miocene sea-level estimates from the New Jersey and Delaware coastal plain coreholes: An error analysis. Basin Research 20(2):211-226, https://doi.org/10.1111/ j.1365-2117.2008.00354.x.

Langebroek, P.M., A. Paul, and M. Schulz. 2009. Antarctic ice-sheet response to atmospheric $\mathrm{CO}_{2}$ and insolation in the Middle Miocene. Climate of the Past 5(4):633-646, https://doi.org/10.5194/ cp-5-633-2009.

Langebroek, P.M., A. Paul, and M. Schulz. 2010. Simulating the sea level imprint on marine oxygen isotope records during the middle Miocene using an ice sheet-climate model. Paleoceanography 25(4), https://doi.org/10.1029/ 2008PA001704.

Lear, C.H., E.M. Mawbey, and Y. Rosenthal. 2010. Cenozoic benthic foraminiferal $\mathrm{Mg} / \mathrm{Ca}$ and $\mathrm{Li} / \mathrm{Ca}$ records: Toward unlocking temperatures and saturation states. Paleoceanography 25(4):PA4215, https://doi.org/10.1029/2009PA001880.

Lenaerts, JTM. S. Lhermitte, R. Drews,

S.R.M. Ligtenberg, S. Berger, V. Helm, C.J.P.P. Smeets, M.R. van den Broeke, W.J. van de Berg, E. van Meijgaard, and others. 2017. Meltwater produced by wind-albedo interaction stored in an East Antarctic ice shelf. Nature Climate Change 7(1):58-62, https://doi.org/10.1038/ nclimate3180.

Levy, R., D. Harwood, F. Florindo, F. Sangiorgi, R. Tripati, H. von Eynatten, E. Gasson, G. Kuhn, A. Tripati, R. DeConto, and others. 2016. Antarctic ice sheet sensitivity to atmospheric $\mathrm{CO}_{2}$ variation in the early to mid-Miocene. Proceedings of the National Academy of Sciences of the United States of America 113(13):3,453-3,458, https://doi.org/ 10.1073/pnas.1516030113.

Levy, R.H., S.R. Meyers, T.R. Naish, N.R. Golledge, R.M. McKay, J.S. Crampton, R.M. DeConto, L. De Santis, F. Florindo, E.G.W. Gasson, and others. 2019. Antarctic ice-sheet sensitivity to obliquity forcing enhanced through ocean connections Nature Geoscience 12:132-137, https://doi.org/ 10.1038/s41561-018-0284-4.

Lewis, A.R., D.R. Marchant, D.E. Kowalewski, S.L. Baldwin, and L.E. Webb. 2006. The age and origin of the Labyrinth, western Dry Valleys, Antarctica: Evidence for extensive middle Miocene subglacial floods and freshwater discharge to the Southern Ocean. Geology 34(7):513-516, https://doi.org/10.1130/G22145.1.

Lewis, A.R., D.R. Marchant, A.C. Ashworth, L. Hedenäs, S.R. Hemming, J.V. Johnson, M.J. Leng, M.L. Machlus, A.E. Newton, J.I. Raine, and others. 2008. Mid-Miocene cooling and the extinction of tundra in continental Antarctica. Proceedings of the National Academy of Sciences of the United States of America 105(31):10,676-10,680, https://doi.org/10.1073/pnas.0802501105.

Liebrand, D., A.T.M. de Bakker, H.M. Beddow, P.A. Wilson, S.M. Bohaty, G. Ruessink, H. Pälike, S.J. Batenburg, F.J. Hilgen, D.A. Hodell, and others. 2017. Evolution of the early Antarctic ice ages. Proceedings of the National Academy of Sciences of the United States of America 114(15):3,867-3,872, https://doi.org/ 10.1073/pnas.1615440114.

Littler, K., T. Westerhold, A.J. Drury, D. Liebrand, L. Lisiecki, and H. Pälike. 2019. Astronomical time keeping of Earth history: An invaluable contribution of scientific ocean drilling. Oceanography 32(1):72-76, https://doi.org/ 10.5670/oceanog.2019.122.

Lunt, D., F. Bragg, W.-L. Chan, D. Hutchinson, J.-B. Ladant, I. Niezgodzki, S. Steinig, Z. Zhang, J. Zhu, A. Abe-Ouchi, and others. 2020. DeepMIP: Model intercomparison of early Eocene climatic optimum (EECO) large-scale climate features and comparison with proxy data. Climate of the Past Discussions, https://doi.org/10.5194/cp-2019-149, in review.

Lunt, D.J., T. Dunkley Jones, M. Heinemann, M. Huber, A. LeGrande, A. Winguth, C. Loptson, J. Marotzke, C.D. Roberts, J. Tindall, and others. 2012. A modeldata comparison for a multi-model ensemble of early Eocene atmosphere-ocean simulations: EoMIP. Climate of the Past 8(5):1,717-1,736 https://doi.org/10.5194/cp-8-1717-2012.

Martínez-Botí, M.A., G.L. Foster, T.B. Chalk, E.J. Rohling, P.F. Sexton, D.J. Lunt, R.D. Pancost, M.P.S. Badger, and D.N. Schmidt. 2015 Plio-Pleistocene climate sensitivity evaluated using high-resolution $\mathrm{CO}_{2}$ records. Nature 518(7537):49-54, https://doi.org/10.1038/ nature14145.

McKay, R.M., P.J. Barrett, R.S. Levy, T.R. Naish, N.R. Golledge, and A. Pyne. 2016. Antarctic Cenozoic climate history from sedimentary records: ANDRILL and beyond. Philosophical Transactions of the Royal Society A 374(2059), https://doi.org/ 10.1098/rsta.2014.0301.

McKay, R.M., L. De Santis, D.K. Kulhanek, and the Expedition 374 Scientists. 2019. Ross Sea West Antarctic Ice Sheet history. Proceedings of the International Ocean Discovery Program, Volume 374, College Station, TX, https://doi.org/ 10.14379/iodp.proc.374.2019.

Mengel, M., A. Levermann, K. Frieler, A. Robinson, B. Marzeion, and R. Winkelmann. 2016. Future sea level rise constrained by observations and longterm commitment. Proceedings of the Nationa Academy of Sciences of the United States of America 113(10):2,597-2,602, https://doi.org/ 10.1073/pnas.1500515113.

Mercer, J. 1978. West Antarctic ice sheet and $\mathrm{CO}_{2}$ greenhouse effect: $A$ threat of disaster. Nature 271(26):321-325, https://doi.org/10.1038/ 271321a0.

Meredith, M., M. Sommerkorn, S. Cassotta, C. Derksen, A. Ekaykin, A. Hollowed G. Kofinas, A. Mackintosh, J. Melbourne-Thomas M.M.C. Muelbert, and others. 2019. Polar regions. Pp. 203-320 in IPCC Special Report on the Ocean and Cryosphere in a Changing Climate. H.-O. Pörtner, D.C. Roberts, V. Masson-Delmotte,
P. Zhai, M. Tignor, E. Poloczanska, K. Mintenbeck, A. Alegría, M. Nicolai, A. Okem, J. Petzold, B. Rama, and N.M. Weyer, eds.

Miller, K.G., J.D. Wright, and R.G. Fairbanks. 1991 Unlocking the ice house: Oligocene-Miocene oxygen isotopes, eustasy, and margin erosion. Journal of Geophysical Research 96:6,829-6,848, https://doi.org/10.1029/90JB02015.

Miller, K.G., J.D. Wright, J.V. Browning, A. Kulpecz, M. Kominz, TR. Naish, B.S. Cramer, Y Rosenthal, W.R. Peltier, and S. Sosdian. 2012. High tide of the warm Pliocene: Implications of global sea level for Antarctic deglaciation. Geology 40(5):407-410, https://doi.org/10.1130/G32869.1.

Miller, K.G., J.V. Browning, W.J. Schmelz, R.E. Kopp, G.S. Mountain, and J.D. Wright. 2020. Cenozoic sea-level and cryospheric evolution from deepsea geochemical and continental margin records. Science Advances 6(20):eaaz1346, https://doi.org/ 10.1126/sciadv.aaz1346

Morlighem, M., E. Rignot, T. Binder, D. Blankenship, R. Drews, G. Eagles, O. Eisen, F. Ferraccioli, R. Forsberg, P. Fretwell, and others. 2020. Deep glacial troughs and stabilizing ridges unveiled beneath the margins of the Antarctic ice sheet. Nature Geoscience 13(2):132-137, https://doi.org/ 10.1038/s41561-019-0510-8.

Moucha, R., A.M. Forte, J.X. Mitrovica, D.B. Rowley, S. Quere, N.A. Simmons, and S.P. Grand. 2008. Dynamic topography and long-term sea-level variations: There is no such thing as a stable continental platform. Earth and Planetary Science Letters 271(1-4):101-108, https://doi.org/10.1016/ j.epsl.2008.03.056.

Mudelsee, M., T. Bickert, C.H. Lear, and G. Lohmann. 2014. Cenozoic climate changes: A review based on time series analysis of marine benthic $\delta^{18} \mathrm{O}$ records. Reviews of Geophysics 52(3):333-374, https://doi.org/10.1002/2013RG000440.

Parizek, B.R., K. Christianson, R.B. Alley, D. Voytenko, I. Vaňková, T.H. Dixon, R.T. Walker, and D.M. Holland. 2019. Ice-cliff failure via retrogressive slumping. Geology 47(5):449-452, https://doi.org/ 10.1130/G45880.1.

Pattyn, F. 2018. The paradigm shift in Antarctic ice sheet modelling. Nature Communications 9(1):10-12, https://doi.org/ 10.1038/s41467-018-05003-z.

Paxman, G.J.G., S.S.R. Jamieson, F. Ferraccioli, M.J. Bentley, N. Ross, E. Armadillo, E.G.W. Gasson, G. Leitchenkov, and R.M. DeConto. 2018. Bedrock erosion surfaces record former East Antarctic Ice Sheet extent. Geophysical Research Letters 45(9):4,114-4,123, https://doi.org/10.1029/ 2018GL077268.

Paxman, G.J.G., S.S.R. Jamieson, K. Hochmuth, K. Gohl, K., M.J. Bentley, G. Leitchenkov, and F. Ferraccioli. 2019. Reconstructions of Antarctic topography since the Eocene-Oligocene boundary. Palaeogeography, Palaeoclimatology, Palaeoecology 535:109346, https://doi.org/ 10.1016/j.palaeo.2019.109346.

Pearson, P.N., G.L. Foster, and B.S. Wade. 2009. Atmospheric carbon dioxide through the Eocene-Oligocene climate transition. Nature 461(7267):1,110-1,113, https://doi.org/ 10.1038/nature08447.

Pekar, S.F., and R.M. DeConto. 2006. Highresolution ice-volume estimates for the early Miocene: Evidence for a dynamic ice sheet in Antarctica. Palaeogeography, Palaeoclimatology, Palaeoecology 231(1-2):101-109, https://doi.org/ 10.1016/j.palaeo.2005.07.027.

Pierce, E.L., T. van de Flierdt, T. Williams, S.R. Hemming, C.P. Cook, and S. Passchier 2017. Evidence for a dynamic East Antarctic ice sheet during the mid-Miocene climate transition. Earth and Planetary Science Letters 478:1-13, https://doi.org/10.1016/j.epsl.2017.08.011.

Pollard, D., and R. DeConto. 2005. Hysteresis in Cenozoic Antarctic ice-sheet variations. Global and Planetary Change 45(1-3):9-21, https://doi.org/ 10.1016/j.gloplacha.2004.09.011. 
Pollard, D., and R.M. DeConto. 2009. Modelling West Antarctic ice sheet growth and collapse through the past five million years. Nature 458:329-332, https://doi.org/10.1038/nature07809.

Pollard, D., R.M. DeConto, and R.B. Alley. 2015. Potential Antarctic Ice Sheet retreat driven by hydrofracturing and ice cliff failure. Earth and Planetary Science Letters 412:112-121, https://doi.org/10.1016/j.epsl.2014.12.035.

Raymo, M.E., R. Kozdon, D. Evans, L. Lisiecki, and H.L. Ford. 2018. The accuracy of mid-Pliocene $\delta^{18} \mathrm{O}$-based ice volume and sea level reconstructions. Earth-Science Reviews 177:291-302, https://doi.org/10.1016/j.earscirev.2017.11.022.

Rignot, E., J. Mouginot, B. Scheuchl, M. van de Broeke, M. van Wessen, and M. Morlighem. 2019. Four decades of Antarctic Ice Sheet mass balance from 1979-2017. Proceedings of the National Academy of Sciences of the United States of America 116(4):1,095-1,103, https://doi.org/10.1073/ pnas.1812883116.

Rintoul, S.R., S.L. Chown, R.M. DeConto, M.H. England, H.A. Fricker, V. Masson-Delmotte, T.R. Naish, M.J. Siegert, and J.C. Xavier. 2018. Choosing the future of Antarctica. Nature 558(7709):233-241, https://doi.org/ 10.1038/s41586-018-0173-4.

Robel, A.A., and A.F. Banwell. 2019. A speed limit on ice shelf collapse through hydrofracture. Geophysical Research Letters 46(21):12,092-12,100, https://doi.org/10.1029/2019GL084397.

Rohling, E.J., F.D. Hibbert, K.M. Grant, E.V. Galaasen, N. Irval, H.F. Kleiven, G. Marino, Y. Ninnemann, A.P. Roberts, Y. Rosenthal, and others. 2019. Asynchronous Antarctic and Greenland icevolume contributions to the last interglacial sealevel highstand, Nature Communications 10:5040, https://doi.org/10.1038/s41467-019-12874-3.

Rose, K.C., F. Ferraccioli, S.S.R. Jamieson, R.E. Bell, H. Corr, T.T. Creyts, D. Braaten, T.A. Jordan, P.T. Fretwell, and D. Damaske. 2013. Early East Antarctic Ice Sheet growth recorded in the landscape of the Gamburtsev Subglacial Mountains. Earth and Planetary Science Letters 375:1-12, https://doi.org/10.1016/j.epsl.2013.03.053.

Sagoo, N., P. Valdes, R. Flecker, and L.J. Gregoire. 2013. The early Eocene equable climate problem: Can perturbations of climate model parameters identify possible solutions? Philosophical Transactions of the Royal Society A 371(2001), https://doi.org/10.1098/rsta.2013.0123.

Sangiorgi, F., P.K. Bijl, S. Passchier, U. Salzmann, S. Schouten, R. McKay, R.D. Cody, J. Pross, T. van de Flierdt, S.M. Bohaty, and others. 2018 Southern Ocean warming and Wilkes Land ice sheet retreat during the mid-Miocene. Nature Communications 9:317, https://doi.org/10.1038/ s41467-017-02609-7.

Schoof, C. 2007. Ice sheet grounding line dynamics: Steady states, stability, and hysteresis. Journal of Geophysical Research 112(F3), https://doi.org/ 10.1029/2006JF000664.

Seroussi, H., and M. Morlighem. 2018. Representation of basal melting at the grounding line in ice flow models. The Cryosphere 12:3,085-3,096, https://doi.org/10.5194/tc-12-3085-2018.

Shackleton, N. 1967. Oxygen isotope analyses and Pleistocene temperatures re-assessed. Nature 215(5096):15-17, https://doi.org/ 10.1038/215015aO.

Shakun, J.D., L.B. Corbett, P.R. Bierman, K. Underwood, D.M. Rizzo, S.R. Zimmerman, M.W. Caffee, T. Naish, N.R. Golledge, and C.C. Hay. 2018. Minimal East Antarctic Ice Sheet retreat onto land during the past eight million years. Nature 558:284-287, https://doi.org/10.1038/ s41586-018-0155-6.

Shevenell, A.E., J.P. Kennett, and D.W. Lea. 2004. Middle Miocene Southern Ocean cooling and Antarctic cryosphere expansion. Science 305(5691):1,766-1,770, https://doi.org/ 10.1126/science.1100061.
Shevenell, A.E., J.P. Kennett, and D.W. Lea. 2008. Middle Miocene ice sheet dynamics, deep-sea temperatures, and carbon cycling: A Southern Ocean perspective. Geochemistry, Geophysics, Geosystems 9(2), https://doi.org/ 10.1029/2007GC001736.

Simkins, L.M., J.B. Anderson, S.L. Greenwood, H.M. Gonnermann, L.O. Prothro, A.R.W. Halberstadt, L.A. Stearns, D. Pollard, and R.M. DeConto. 2017. Anatomy of a meltwater drainage system beneath the ancestral East Antarctic Ice Sheet. Nature Geoscience 10(9):691-697, https://doi.org/10.1038/ ngeo3012.

Spears, A., M. West, M. Meister, J. Buffo, C. Walker, T.R. Collins, A. Howard, and B. Schmidt. 2016. Under ice in Antarctica. IEEE Robotics and Automation Magazine 23(4):30-41, https://doi.org/ 10.1109/MRA.2016.2578858

Stap, L.B., J. Sutter, G. Knorr, M. Stärz, and G. Lohmann. 2019. Transient variability of the Miocene Antarctic Ice Sheet smaller than equilibrium differences. Geophysical Research Letters 46(8):4,288-4,298, https://doi.org/ 10.1029/2019GL082163.

Stocchi, P., C. Escutia, A.J.P. Houben, B.L.A. Vermeersen, P.K. Bijl, H. Brinkhuis, R.M. DeConto, S. Galeotti, S. Passchier, D. Pollard, and others. 2013. Relative sea-level rise around East Antarctica during Oligocene glaciation. Nature Geoscience 6(5):380-384, https://doi.org/10.1038/ NGEO1783.

Treasure, A.M., F. Roquet, I.J. Ansorge, M.N. Bester L. Boehme, H. Bornemann, J.-B. Charrassin, D. Chevallier, D.P. Costa, M.A. Fedak, and others 2017. Marine mammals exploring the oceans pole to pole: A review of the MEOP consortium. Oceanography 30(2):132-138, https://doi.org/ 10.5670/oceanog.2017.234.

Trusel, L.D., K.E. Frey, S.B. Das, P.K. Munneke, and M.R. Van Den Broeke. 2013. Satellite-based estimates of Antarctic surface meltwater fluxes. Geophysical Research Letters 40(23):6,148-6,153, https://doi.org/10.1002/2013GL058138.

Turney, C.S.M., C.J. Fogwill, N.R. Golledge, N.P. Mckay, E. van Sebille, R.T. Jones, D. Etheridge, M. Rubino, D.P. Thornton, S.M. Davies, and others. 2020. Early Last Interglacial ocean warming drove substantial ice mass loss from Antarctica. Proceedings of the National Academy of Sciences of the United States of America 117(8):3,996-4,006, https://doi.org/ 10.1073/pnas.1902469117.

Warny, S., R.A. Askin, M.J. Hannah, B.A.R. Mohr, J.I. Raine, D.M. Harwood, and F. Florindo. 2009. Palynomorphs from a sediment core reveal a sudden remarkably warm Antarctica during the middle Miocene. Geology 37(10):955-958, https://doi.org/ 10.1130/G30139A.1.

Whitehouse, P.L., N. Gomez, M.A. King, and D.A. Wiens. 2019. Solid Earth change and the evolution of the Antarctic Ice Sheet. Nature Communications 10(503), https://doi.org/10.1038/ s41467-018-08068-y.

Wilson, D.J., R.A. Bertram, E.F. Needham, T. van de Flierdt, K.J. Welsh, R.M. McKay, A. Mazumder, C.R. Riesselman, F.J. Jimenez-Espejo, and C. Escutia. 2018. Ice loss from the East Antarctic Ice Sheet during late Pleistocene interglacials. Nature 561(7723):383-386, https://doi.org/10.1038/ s41586-018-0501-8.

Winkelmann, R., A. Levermann, A. Ridgwell, and K. Caldeira. 2015. Combustion of available fossil fuel resources sufficient to eliminate the Antarctic Ice Sheet. Science Advances 1(8):e1500589, https://doi.org/10.1126/sciadv.1500589.

Winnick, M.J., and J.K. Caves. 2015. Oxygen isotope mass-balance constraints on Pliocene sea level and East Antarctic Ice Sheet stability. Geology 43(10):879-882, https://doi.org/10.1130/ G36999.1.
Wise, M.G., J.A. Dowdeswell, M. Jakobsson, and R.D. Larter. 2017. Evidence of marine ice-cliff instability in Pine Island Bay from iceberg-keel plough marks. Nature 550(7677):506-510, https://doi.org/ 10.1038/nature24458.

Young, D.A., A.P. Wright, J.L. Roberts, R.C. Warner, N.W. Young, J.S. Greenbaum, D.M. Schroeder, J.W. Holt, D.E. Sugden, D.D. Blankenship, and others. 2011. A dynamic early East Antarctic Ice Sheet suggested by ice-covered fjord landscapes. Nature 474(7349):72-75, https://doi.org/10.1038/ nature10114.

Zachos, J.C., J.R. Breza, and S.M. Wise. 1992. Early Oligocene ice-sheet expansion on Antarctica: Stable isotope and sedimentological evidence from Kerguelen Plateau, southern Indian Ocean. Geology 20(6):569-573, https://doi.org/10.1130/ 0091-7613(1992)020<0569:EOISEO>2.3.CO;2.

Zachos, J.C., G.R. Dickens, and R.E. Zeebe. 2008 An early Cenozoic perspective on greenhouse warming and carbon-cycle dynamics. Nature 451(7176):279-283, https://doi.org/10.1038/ nature06588.

Zelinka, M.D., T.A. Myers, D.T. McCoy, S. Po-Chedley, P.M. Caldwell, P. Ceppi, S.A. Klein, and K.E. Taylor. 2020. Causes of higher climate sensitivity in CMIP6 models. Geophysical Research Letters 47(1):e2019GL085782, https://doi.org/ 10.1029/2019GL085782.

Zhang, Y.G., M. Pagani, Z. Liu, S.M. Bohaty, and R. DeConto. 2013. A 40-million-year history of atmospheric $\mathrm{CO}_{2}$. Philosophical Transactions of the Royal Society A 371:20130096, https://doi.org/ 10.1098/rsta.2013.0096.

Zhu, J., C.J. Poulsen, and J.E. Tierney. 2019

Simulation of Eocene extreme warmth and high climate sensitivity through cloud feedbacks. Science Advances 5(9):eaax1874, https://doi.org/10.1126/ sciadv.aax1874.

Zhu, J., C.J. Poulsen, and B.L. Otto-Bliesner. 2020 High climate sensitivity in CMIP6 model not supported by paleoclimate. Nature Climate Change 10:378-379, https://doi.org/10.1038/ s41558-020-0764-6.

\section{ACKNOWLEDGMENTS}

E.G. thanks the Royal Society and Natural Environment Research Council (NERC) grant "PLIOAMP" (NE/T007397/1) for financial support. B.K. is funded by a Lamont-Doherty Postdoctoral Fellowship. We thank Bas de Boer and guest editor Amelia Shevenell for comments that greatly improved the manuscript.

\section{AUTHORS}

Edward G.W. Gasson (e.gasson@bristol.ac.uk) is Royal Society University Research Fellow, School of Geographical Sciences, University of Bristol, Bristol, UK. Benjamin A. Keisling is Postdoctoral Research Scientist, Lamont-Doherty Earth Observatory of Columbia University, Palisades, NY, USA.

\section{ARTICLE CITATION}

Gasson, E.G.W., and B.A. Keisling. 2020. The Antarctic Ice Sheet: A paleoclimate modeling perspective. Oceanography 33(2):90-100, https://doi.org/10.5670/ oceanog.2020.208.

\section{COPYRIGHT \& USAGE}

This is an open access article made available under the terms of the Creative Commons Attribution 4.0 International License (https://creativecommons.org/ licenses/by/4.0/), which permits use, sharing, adaptation, distribution, and reproduction in any medium or format as long as users cite the materials appropriately, provide a link to the Creative Commons license, and indicate the changes that were made to the original content. 